Perilloides Schouteden.

(Perillus Stal., in part.)

P. exaptus Say. 19 May-30 Aug. Orono, Wales, Monmouth.

P. circumcinctus Stal. 17 May. Pownal.

Zicrona Amyot et Serville.

Z. cærulea Linn. 22 to 24 June. Newbury Neck, near Surrey.

I have one specimen of this species taken by Mr. F. A. Eddy on the coast. As far as I know it has hitherto been reported only from the West and from Mt. Washington, N. H.

Apateticus Dallas.

(= Podisus Herrich-Schaeffer.)

A. cynicus Say. 25 Aug.-2 Sept. Orono. Pittsfield.

A. bracteatus Fitch. 6-24 Aug. Long Island in Penobscot Bay, Houlton.

A. maculiventris Say. 11 June-13 Sept. Orono, Norway, Pownal.

A. sereiventris Uhler. 29 May-3 Aug. Orono.

A. modestus Dallas. 24 June-17 Aug. Orono, Bangor, Pownal, Monmouth.

FAMILY THYREOCORID 2 .

(incl. Cydnido)

Sehirus Amyot et Serville.

S. cinctus Pal.-Beauv. 30 April-31 Aug. The Forks, Orono, Bangor, Chamberlain Lake.

Thyreocoris Schrank.

T. nitiduloides Wolff. 14 June-21 Aug. Orono, Deering, Norway.

T. pulicaria Germ. 8 May. Orono.

T. unicolor Pal.-Beauv. 30 April-15 Sept. Orono, Pownal, Norway.

FAMILY SCUTELLERID $A$.

Homœmus Dallas.

H. æneifrons Say. 22 July-12 Sept. Orono, Machias, Ft. Kent, Ashland.

Eurygaster Laporte.

E. alternata Say. 8 May-21 Aug. Orono, Houlton, Pownal, W. Beach.

\title{
NEW AND LITTLE KNOWN HARVESTING ANTS OF THE GENUS POGONOMYRMEX. ${ }^{1}$
}

\section{By William Morton Wheeler.}

\section{Pogonomyrmex guatemaltecus sp. nov.}

Worker. Length 5-5.5 mm.

Head subrectangular, excluding the mandibles a little longer than broad, with nearly straight sides, feebly excised posterior margin and prominent anterior cor-

${ }^{1}$ Contributions from the Entomological Laboratory of the Bussey Institution, Harvard University, No. 80 . 
ners. Eyes rather small and flat, elliptical, just in front of the median transverse diameter of the head. Mandibles convex, with five subequal teeth. Clypeus short, feebly convex, its anterior border strongly bidentate, arcuately excised between the teeth, sinuate laterally. Frontal area distinct, with a median carinula. Antennal scapes reaching less than half the distance between the eyes and posterior corners of the head; funicular joints 2-10 scarcely longer than broad. Thorax short, but little longer than the head without the mandibles, broadest through the pronotum, somewhat compressed behind; in profile the dorsal outline is usually convex and evenly rounded as far back as the boundary between the epinotal base and declivity. These meet at an obtuse angle, the declivity being shorter than the base, descending perpendicularly and forming a right angle on each side with the metasternal angle which is sharp and rectangular in profile. There are no traces of spines or teeth on the epinotum. Petiole with a slender, laterally compressed peduncle which is nearly as long as the node and armed with a distinct anteroventral tooth; node compressed anteroposteriorly and rounded in front, slightly overarching the peduncle, with which its straight or slightly concave anterior surface forms at least a right angle and in some specimens even an acute angle in profile; seen from above the posterior surface is subelliptical, nearly twice as long as broad, and with rounded and not acute anterior border. Postpetiole campanulate, a little broader than the petiole, broader behind than in front, in profile very convex both dorsally and ventrally. Gaster elliptical, smaller than the head. Legs well developed.

Body, but especially the mandibles and gaster, shining. Mandibles very coarsely longitudinally striated. Clypeus and head covered with coarse longitudinal rugæ, subparallel on the head and diverging only very slightly from the median line and not till they reach the occiput. Interrugal spaces reticulate and feebly punctate. Anterior depressed portion of pronotum transversely rugulose; remainder of pronotum, the mesonotum and pleuræ coarsely and longitudinally reticulate-rugose. Rugæ on the epinotum finer and transverse. Petiolar peduncle smooth and shining, posterior surface of node coarsely longitudinally reticulate-rugose. Postpetiole subopaque, finely and densely reticulate-punctate. Upper surface of gaster with sparse piligerous foveolæ, which are somewhat more closely aggregated near the anterior margin of the first segment. Legs very finely shagreened with small, sparse, piligerous punctures. Antennal scapes longitudinally rugulose.

Hairs pale yellow, stiff, pointed, erect, varying in length, generally distributed over the body and appendages. Ammochætæ on clypeus, ventral surfaces of mandibles and gula long, but on the gula forming only a small psammophore, i.e., the long hairs surround only the anterior portion of the gula and do not enclose the whole of it as in most species of Pogonomyrmex sens. str.

Color deep red, legs and base of first gastric segment slightly paler; teeth of mandibles black; anterior border of clypeus, posterior border of first gastric segment and a transverse band on each of the remaining segments dark brown or blackish.

Female (deälated). Length nearly $7 \mathrm{~mm}$.

Very similar to the worker. Rugosity of thorax finer and more regular. Gaster larger, with the black banding of the segments more distinct, but the punctures on the dorsal surface smaller and less foveolate. 
Described from a large number of workers and a single female, which I took December 12-14, 1911, from many nests at Zacapa, Guatemala, in the extremely arid plains known as "La Fragua," a region with pronounced xerophytic vegetation (giant cacti, etc). The ants were nesting in the fields, the grass of which, at the time of my visit, was parched and had been eaten down to the roots by the cattle. The nests were regular, flattened craters from 3-8 inches in diameter, not surrounded by clearings, and much like the nests of the other small North American species of Pogonomyrmex. A pile of grass-seed or chaff, often found to one side of the crater, showed that the species is granivorous like other members of the genus. Many nests were also found in the sand-ballast of the railroad near the town of Zacapa. The worker is readily distinguished from that of most of the described species of Pogonomyrmex by the peculiar shape of the thorax, clypeus and petiole and by the 5 -toothed mandibles.

\section{Pogonomyrmex huachucanus sp. nov.}

Worker. Length 4.5-5 mm.

Head subrectangular, excluding the mandibles as broad as long, with nearly straight lateral and feebly excised posterior margin. Eyes elliptical, rather convex, at the middle of the sides of the head. Mandibles with convex external and rather oblique apical borders, the latter 6 -toothed. Clypeus moderately convex, its anterior border marginate, distinctly bidentate and arcuately excised between the teeth. Frontal area distinct, with median carinula. Antennæ not reaching halfway between the eyes and the posterior corners of the head; first and second funicular joints distinctly longer than broad, remaining joints, except the last, as long as broad. Thorax slightly longer than the head without the mandibles, from above broadest through the pronotum, but with the transverse diameters of the mesoand epinotum equal; in profile the dorsal outline is convex in the pronotal region but the mesonotum and base of the epinotum form a straight line gently sloping to the two spines, which are shorter than the base of the epinotum, rather slender but blunt, closely approximated at their bases and directed upward, outward and slightly backward. The epinotal declivity is short, abrupt and much as in $P$. guatemaltecus, forming in profile a right angle with the metasternal angles, which are in turn rectangular. Petiole with slender, laterally much compressed peduncle half as long as the node and with a distinct but rather blunt anteroventral tooth. Node from above subelliptical, pointed or acuminate in front, less than twice as long as broad, its posterior surface rather sharply marked off from the anterior, so that the summit appears pointed also in profile. The anterior surface is slightly convex in profile and rises abruptly and perpendicularly from the peduncle, the posterior surface, also slightly convex, is about one and one half times as long as the anterior and constricted near its posterior end. Postpetiole from above sub- 
globular, a little broader behind than in front, a little broader than long and somewhat broader than the petiolar node. In profile the dorsal surface is very convex, the ventral bears a rounded boss in its middle. Gaster elliptical, proportionally larger than in $P$. guatemaltecus

Mandibles, gaster and legs shining, remainder of body appearing more subopaque, owing to their sculpture. Mandibles longitudinally striated; clypeus and head longitudinally rugose, the rugæ being moderately strong and numerous and distinctly and gradually diverging from the median line towards the posterior corners; the interrugal spaces densely punctate. Thorax throughout reticulately rugose, the rugæ being somewhat coarser and further apart than on the head, longitudinal on the pronotum and pleuræ and arcuately transverse on the mesonotum and base of the epinotum. Peduncle and anterior surface of petiolar node shining, finely shagreened, posterior surface coarsely and irregularly rugose and punctate. Postpetiole finely and densely punctate. Gaster very smooth and shining even at the base, with minute and sparse piligerous punctures. Legs finely shagreened and sparsely punctate, antennal scapes longitudinally rugulose.

Hairs pale yellow, erect, of unequal length, covering all parts of the body, longest on the dorsal surface. Ammochætæ well-developed on the clypeus, ventral surfaces of mandibles and gula, but the psammophore is restricted as in P. guatemaltecus and does not extend to the posterior and lateral borders of the head.

Deep red, lower surface of head, the legs, coxæ and gaster paler and more yellowish; dorsal surface of first gastric segment with a dark brown cloud on each side and usually with a median longitudinal streak of the same color. Mandibular teeth and anterior border of clypeus black.

Described from twenty-two specimens taken by myself November 11, 1910, from a single nest on the rocky southern wall of Miller Canyon in the Huachuca Mountains, Arizona, at an altitude of about 5,600 feet. This nest was under a small, flat stone and resembled the nests of $\boldsymbol{P}$. (Ephebomyrmex) imberbiculus Wheeler, which I have seen in the mountains of Texas.

At first sight $P$. huachucanus resembles guatemaltecus, but closer comparison reveals many differences, especially in the shape of the thorax and petiole, not the least being the presence of epinotal spines in the former species. This is, indeed, unlike any of the known North American species but singularly close to $P$. bispinosus Spinola of Chili, as I find by comparison with cotypes of the variety semistriatus Emery received from Professor Silvestri. The thorax in bispinosus, however, is more flattened dorsally in front than in huachucanus, the metasternal angles are rounder, the petiolar node is lower and the postpetiole is as long as broad and less globular. The gaster of the typical bispinosus is said to be smooth and shining as in huachucanus, but in the variety semistriatus its 
base is opaque and finely punctate-striolate. These differences are all so slight that huachucanus may eventually prove to be merely a subspecies of bispinosus. The resemblances between the two forms, separated by such a wide territory, is very suggestive in connection with the origin of the genus Pogonomyrmex. Owing to the fact that this genus is represented by the greatest number of species in North America, and that it is most closely related to the boreal genus Myrmica, it has been assumed that the species of Pogonomyrmex originated in the western United States and migrated thence along the arid plains and mountain ranges through Mexico, Central and South America as far as Patagonia. On this assumption, $P$. huachucanus might be regarded as a rare relict of a group of species which once ranged over a large portion of western America, but now survive only in Chili and the Huachuca Mountains of Arizona.

$P$. huachucanus and guatemaltecus, together with bispinosus and two other South American species, brevibarbis Emery and silvestrii Emery, are also of considerable interest, because in the restricted area of the gula enclosed by the long hairs of the psammophore and in sculpture they are transitional between the species of Pogonomyrmex sens. str. and the subgenus Ephebomyrmex Wheeler. The acute, spinose character of the metasternal angles in brevibarbis and silvestrii reveals a still closer relationship to the latter subgenus. All of these species may, therefore, represent today the most primitive and ancestral forms from which both subgenera have been evolved.

\section{Pogonomyrmex californicus Buckley.}

The worker of the typical form of this species measures $5.5-6 \mathrm{~mm}$. and is characterized by the shape of the petiole and the sculpture. The anterior surface of the petiolar node forms very nearly a right angle with the upper surface of the peduncle, and the ventral surface of the latter bears no tooth. The surface of the body is shining, the rugæ of the head and thorax being sharp and pronounced, the spaces between them impunctate or with punctures so small and shallow as to be barely visible under a magnification of 20 diameters. The petiolar and post-petiolar nodes are very finely and densely punctate and indistinctly rugulose. The body is light ferruginous red, the mandibles, clypeus and legs more yellowish.

The female measures about $8 \mathrm{~mm}$. and resembles the worker very closely in form, sculpture and color. The head is somewhat broader than long. Wings hyaline, with their basal portions distinctly yellowish, the veins and stigma brown.

The male measures $7.5 \mathrm{~mm}$. and has rather broad mandibles, with oblique 4toothed blades. Head, thorax, nodes of petiole and postpetiole, coxæ and femora, 
except their bases and tips, and base of first gastric segment, black; remainder of body red, the mandibles and antennæ being more brownish, the gaster more yellowish in tint. Wings colored as in the female.

No type-locality in California is mentioned in Buckley's original description. I have seen numerous specimens from the following places:

California: Lakeside, Pasadena and Claremont (Wheeler); Point Loma, near San Diego (P. I.eonard); San Pedro (T. D. A. Cockerell); Lompoc and Upland (J. C. Bradley); San Jacinto; Sierra Valley.

Arizona: Yuma (Wheeler).

Nevada: Las Vegas (J. C. Bradley)

This ant is very common in the sandy canyon bottoms of southern California. Its nests are flat craters 4-10 inches in diameter, with sloping, central or eccentric entrances. The workers are agile hunters of insects when these are to be found, but at certain seasons of the year large numbers of seeds are collected and stored in the nests. The nests in the Arroyo Seco, at Pasadena, Cal., were often found covered with the seeds of a common canyon shrub (Eriogonum fasciculatum) during the month of December.

\section{Pogonomyrmex californicus Buckley subsp. estebanius Pergande.}

This form, which should be regarded as a subspecies and not as a variety, averages a little smaller in all three phases than the typical californicus. In the worker the rugæ of the head and thorax are decidedly more delicate, but the interrugal punctures are quite as indistinct. The anterior surface of the petiolar node is more sloping and therefore forms a larger obtuse angle with the upper surface of the peduncle, and the node is lower than in the typical form of the species. There is also a tendency to develop a tooth on the anteroventral surface of the petiole. Typically the gaster is black, with the base of the first segment yellowish red; but specimens are sometimes found with only the tip of the gaster black or with a few black spots on the first segment, usually near its lateral or posterior borders. The nodes are sometimes infuscated; more rarely the whole gaster is black.

The female varies considerably in size, from 7-9 $\mathrm{mm}$; and the gaster varies greatly in color. In most of my specimens it is entirely black, except for a large, bilobed, yellowish red spot at the base of the first segment. In others only the lateral and posterior margins of this segment are black and often the markings are interrupted in the middorsal line. The veins of the wings are pale yellow, but the stigma is brown.

The male measures 6.5-8.5 mm. Its mandibles are narrow, with transverse, bidentate, apical borders. Its color resembles that of the typical californicus, except that the gaster is in some specimens entirely red, in others entirely black. In some specimens, too, more or less of the anterior portion of the head may be red.

Lower California: Calmalli Mines, San Esteban, type locality; San Borgia and Margarita Island (Eisen and Haines).

California: Needles (Wheeler); Otis (J. C. Bradley). 
Arizona: Yuma, Yucca, Tucson and Phoenix (Wheeler); Nogales (Oslar); Florence.

This subspecies is very abundant in the hot deserts of California and Arizona, but according to my observations it nests only in pure sand.

5. Pogonomyrmex californicus Buckley subsp. longinodis Emery.

I fail to find this form among the large amount of material I have collected, and am inclined to believe that it must be either very rare or local. It was described by Emery as follows from specimens taken in the Colorado Desert of California and received from Pergande: "The worker differs from that of $P$. californicus in its more slender pedicel, the second joint of which [i.e. the postpetiole] is not as high as long; the peduncle of the first joint [petiole] is shorter than the very long and anteriorly pointed node. Sculpture feebler than in californicus; pedicel merely finely punctate, without rugæ. Color rather light red, abdomen, with the exception of the pedicel and its base, brown."

6. Pogonomyrmex californicus Buckley subsp. maricopa subsp. nov.

The worker of this form measures $6-7.5 \mathrm{~mm}$. and therefore averages larger than the typical californicus from which it differs in the shape of the petiole and in sculpture. The node of the petiole is less pointed above, its anterior surface is straight and forms an obtuse angle with the upper surface of the peduncle, and there is often a distinct anteroventral tooth. The petiole is fully as long as high. The rugæ of the head and thorax are much less prominent and the spaces between them are filled densely with very distinct punctures, clearly visible under a magnification of 20 diameters. The surface of the head and thorax are decidedly subopaque and not shining as in the typical californicus. The nodes of the petiole and postpetiole are also more coarsely shagreened and less shining. The color is the same.

A single deälated female from Rincon, New Mexico, measures $8 \mathrm{~mm}$. and closely resembles the female of the typical form in sculpture, the rugæ of the head and thorax being sharp, the interrugal punctures rather indistinct.

New Mexico: Alamogordo, type locality (G. von Krockow); Prescott and Albuquerque (Wheeler); Roswell, Deming and El Rincon (T. D. A. Cockerell); Las Truches (Miss Lillie Gerhardt); Engle (Miss Nora Newberry.)

Arizona: Yuma, Tucson, Benson and Grand Canyon (Wheeler).

California: Needles (Wheeler).

Texas: Marfa (Wheeler); Barton (J. C. Crawford); Victoria (J. D. Mitchell); Chisos Mts., $4600 \mathrm{ft}$. (W. B. Phillips).

Mexico: Ojos del Diablo and Ojos de San Dijuela in Chihuahua (C. H. T. Townsend).

As shown by this list of localities, maricopa ranges much further 
to the east, through the deserts of New Mexico and Texas, than the other subspecies of californicus, and usually occurs at greater elevations. Its nests are very similar, being flat craters in sand, with sloping central or eccentric entrances.

\section{Pogonomyrmex subnitidus Emery.}

If I am correct in my identification, this form is not a subspecies of $P$. occidentalis Cresson, as Emery supposed, but a distinct species. Emery's description is unfortunately very brief, but I believe that it refers to a form which I found nesting in the vicinity of Pasadena, California, both in the higher portions of the Arroyo Seco and on the summit of Mt. Lowe (6400 ft.). I have also received a series of workers of the same form from Mr. J. C. Bradley, who took them in Los Gatos Canyon of the Diablo Range in the same state. The nests are like those of californicus and therefore entirely unlike the nests of occidentalis. The sculpture of the head, thorax and pedicel of the worker, moreover, is very much like that of the true californicus, but the epinotum is armed with two slender, pointed spines, which are longer than in occidentalis.

\section{Pogonomyrmex comanche Wheeler.}

This form, which was also originally described as a subspecies of occidentalis, must now be regarded as an independent species. In the worker comanche the thoracic dorsum is distinctly more rounded and arched in profile than in the worker occidentalis and the epinotal spines are longer both in the worker and female, but especially in the latter. There is also a great difference in the mandibles of the males of the two species, the blade in the male occidentalis being moderately broad with oblique apical border bearing 5 or 6 teeth, whereas in comanche it is narrow and more curved and its apical border is transverse and only 3-4-toothed. The epinotum of the male comanche bears a pair of small teeth, which are represented by tubercles in occidentalis. The greatest difference between the two species, however, is seen in the habits and distribution, comanche living at low levels in pure sand, where it makes rather small, flat crater nests very much like those of californicus, whereas occidentalis lives at elevations over 6,000 feet, and constructs large gravel cones with basal entrance and surrounded by a clearing. The colonies of the latter species are also much more populous. The types of comanche were taken in the 
sandy post oak woods at Montopolis, near Austin, Texas. I have taken the species also at Milano in the same state.

A study of comanche, subnitidus, californicus and its subspecies maricopa shows that these forms have essentially the same habits and are all very closely and peculiarly related. Without its spines the worker subnitidus would be indistinguishable from the worker californicus, and the same relation obtains between comanche and maricopa. As it seems evident that the spined species of Pogonomyrmex must be more primitive that the spineless forms, it is not improbable that subnitidus is really the parent species of californicus and comanche the parent species of maricopa. If further study supports this conclusion, maricopa will have to be regarded as a. distinct species.

\section{FORFICULA AURICULARIA IN RHODE ISLAND.}

By R. W. Glaser, Bussey Institution, Harvard University.

Since all previous records of Forficula auricularia in America are very dubious, a report of the occurrence of large numbers of this species of earwig in Newport, Rhode Island, seems advisable.

While in Newport in July, 1914, I heard that the estate of Mr. T. Suppern Tailer was infested with earwigs and that they were making themselves extremely disagreeable by entering the house and crawling over people at night. I went to the estate and found literally hundreds of what I then supposed to be the European earwig. Mr. James A. G. Rehn of the academy of natural sciences. in Philadelphia and Mr. A. P. Morse of Wellesley, Mass., have since kindly identified the species as $\boldsymbol{F}$. auricularia Linn.

I found the insects hiding in all possible places during the day. They were abundant in the cracks of stone walls, under porches and behind vines. They were also taken from the inside of flowers in large numbers.

According to Mr. Tailer and his gardener, the earwigs were first noticed in 1912. In 1913 they increased to such an extent that suppression work by spraying was begun and at the time of writing this note (July, 1914), they seemed to have passed beyond control and have spread to adjoining estates. No one seems to be able 

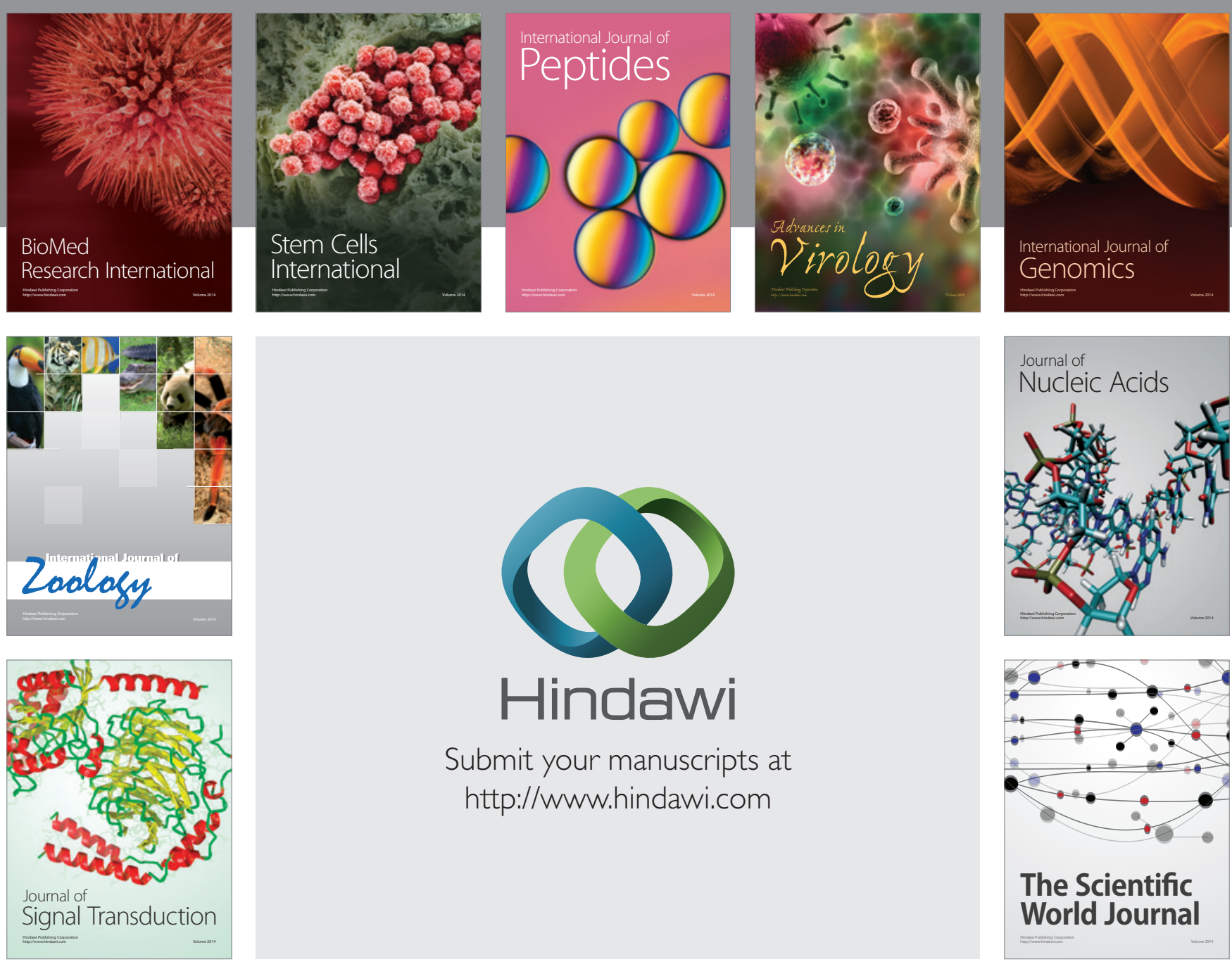

Submit your manuscripts at

http://www.hindawi.com
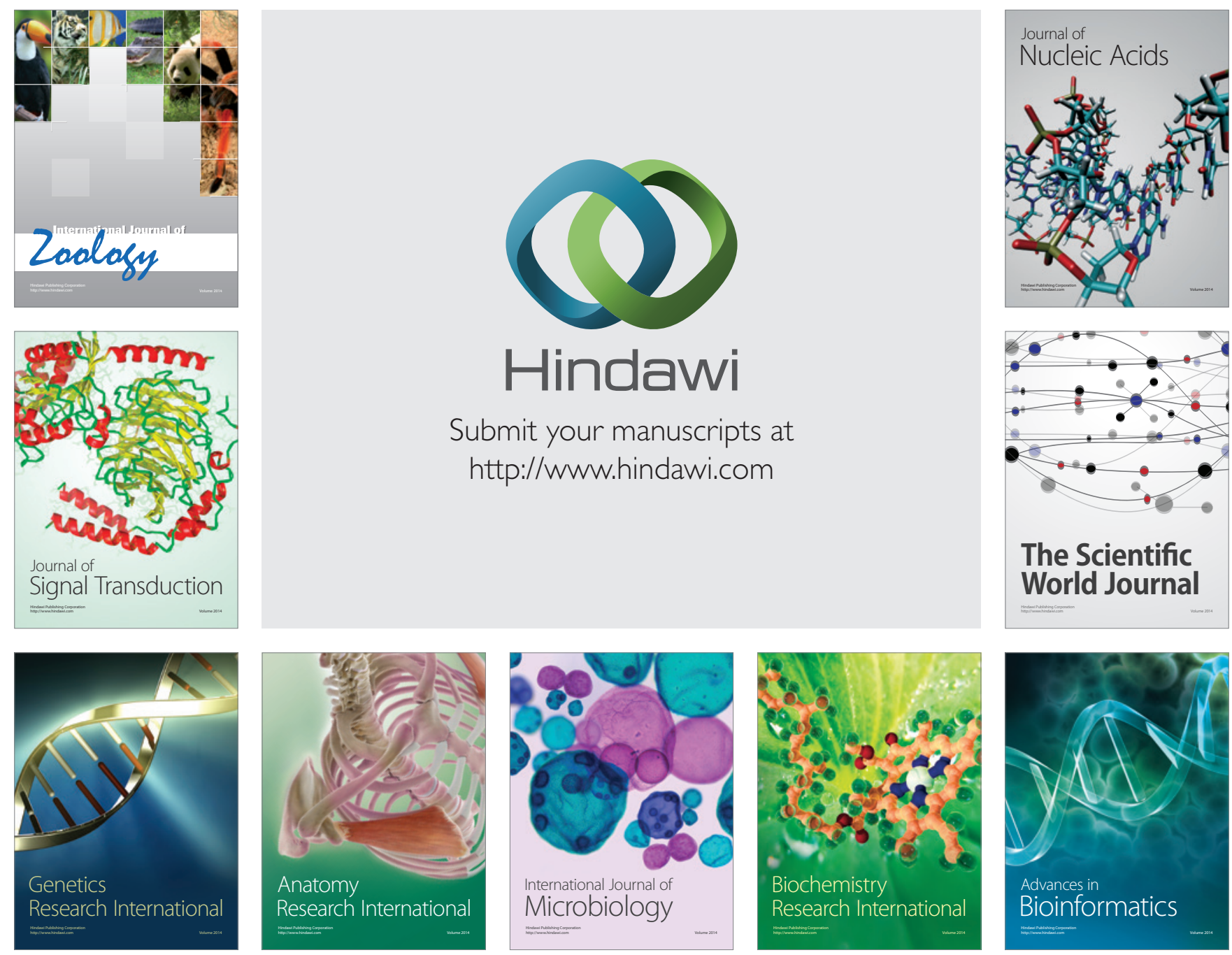

The Scientific World Journal
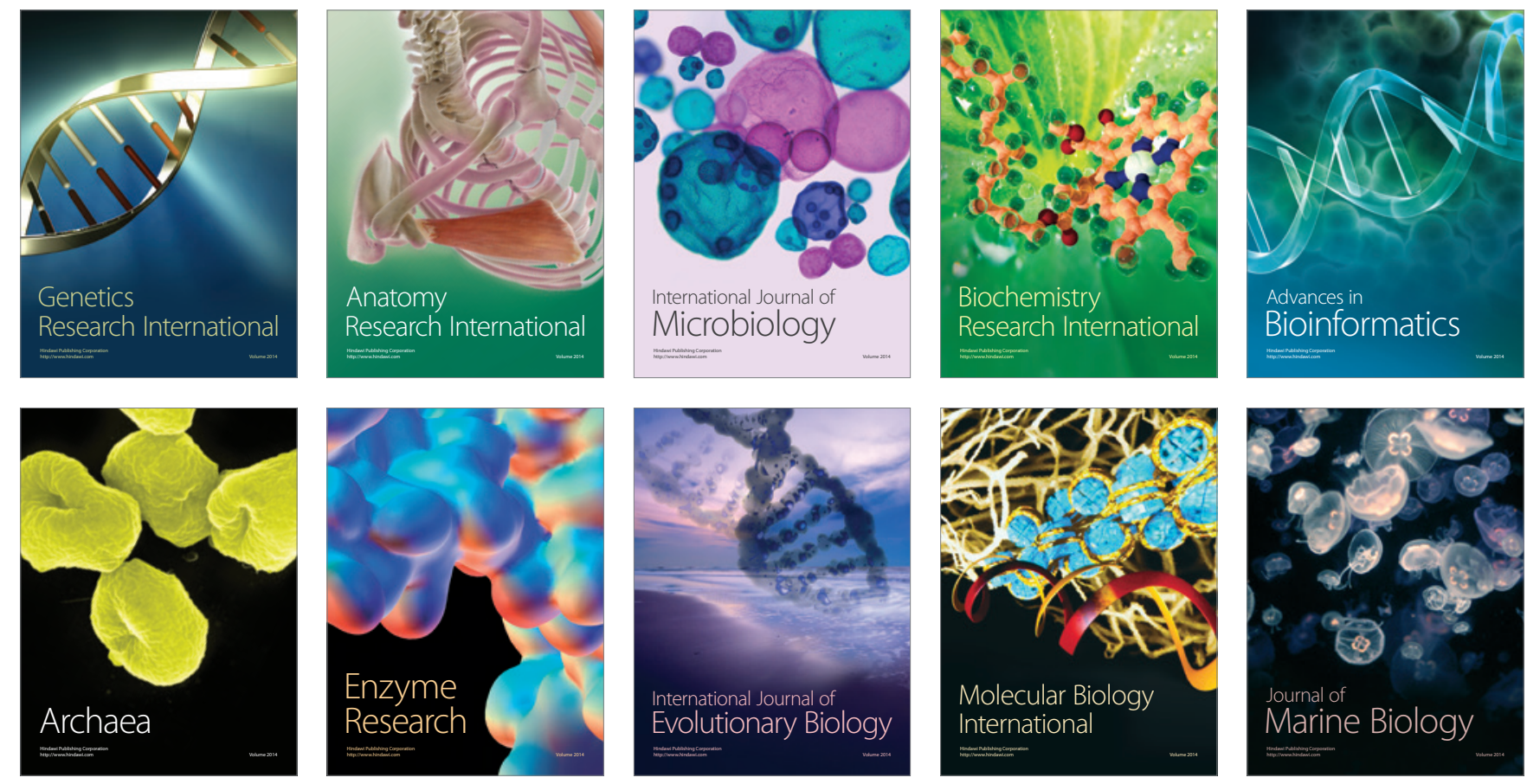